\title{
Popular Catholicism Based on Sensory Engagement and Corporeal Perception
}

\author{
Euna Lee \\ Seoul National University, Seoul, Korea
}

\begin{abstract}
Pat Mora's House of Houses is a collection of memories about a Southwestern Mexican immigrant family. She develops multilayered meanings of the house in terms of psychological, spiritual, and sensory influences on both her private and communal life. She deploys sensory signifiers to portray religious and spiritual memories in a picturesque or performative way. The book reveals that the primacy of the senses as a perceptual device transforms the habitual religious rituals of popular Catholicism into the unconscious. This book shows how sensory perception is engaged in appropriating mystical space/time and interiorizing spiritual objects of family life. Thus, the paper investigates how the sensory agencies contribute to exploring culturally plural ways of experiencing the divine. It also illustrates how Mora's deployment of corporeality is related to her reassessment of femaleness and understanding of a meaning of the divine, which is distinctively embodied through lo cotidiano. In effect, it focuses on Mora's treatment of the sensible body in connection with spiritual and religious connotations.
\end{abstract}

Keywords: Pat Mora, House of Houses, popular Catholicism, sensory perception, corporeality

\section{Introduction}

Mora's (1997) House of Houses, both as an autobiographical memoir and as a collection of memories, reconstructs the story of her family through the fusion of reality, fantasy, and imagination. Mora projects her imaginative interpretation into the representation of reality: she combines her poetic fictionality with what remains in the family's memoirs. In this respect, the house can be resignified as a "dwelling that shapes us" (p. 272) through dreams and the unconscious as Gaston Bachelard defines in The Poetics of Space. She draws on them to resurface visibly.

Due to the full engagement of the senses, Mora accompanies boundless links between the living and the dead, here and there, indeed body and spirit. The paper examines her deployment of sensory signifiers both as a dominant textual strategy and as an enactment of spirituality in her family. This paper delves into "authentic" meanings of her spiritual quest by studying how popular Catholicism is transmitted and inherited through the senses as the memoir recuperates the repressed corporeality of official religious culture. It will investigate how the sensory agencies contribute to exploring the culturally plural ways of experiencing the sacred. The analysis will also take into account Mora's desire to discover a particular religiosity. In effect, the paper illustrates how sensory faculties and corporeal perception are engaged in appropriating spiritual space/time and interiorizing religious objects of family life.

Euna Lee, Ph.D., BK professor, Department of Hispanic Language and Literature, Seoul National University. 


\section{The Deployment of the Senses as Perceptive Devices of Religion}

It is evident that the memoir is partly a subtext of biblical messages because it clearly shows how she accommodates the Catholic heritage in her particular cultural environment. Nevertheless, Mora crafts a personal spiritual outlook that neither dissociates itself from religious orthodoxy nor binds to it. Her remark on Catholicism may hint at this position:

What I am very much interested in is the power of faith and spirit in our lives. And the natural world is part of that interest, how we can deepen our awareness of what our work should be in this world. But I do not tie it to a particular institutionalized religion. I will always be fascinated by Roman Catholicism because of its role in my life as well as its role in the history of Mexico and the Southwest. (Mora, cited in Ikas, 2002, p. 144)

Mora herself no longer practices Catholicism, but she admits that she misses the "protected intimacy” (p. 3) of the church: the same affinity afforded her at home. Her fondness for the church is explicitly expressed by detailing the sensory impressions that she experienced in church:

Opening a choir book, I press my fingers on the desk the way I used to press piano keys, in the majestic style of organ music. I'll always be nostalgic for the old church, the Latin church, the invisible choir, the priest's back rather than his face, the intoxication of incense and flickering candles. (Mora, 1997, p. 18)

For Mora, the religious experience during her adolescence is more intuitively embedded rather than indoctrinated into her senses. The familiarity with visible and audible characteristics of the indoors appears to allow her to remember "the pleasure of being encircled by earth, the poetry of place" (p. 3), while she is writing the memoir.

Mora articulates that what she encapsulated through sensory faculties was elevated into the spiritual, which eventually inhabited itself deeply in the realm of the unconscious. She explains, "In our creations, the unconscious surfaces, becomes visible, and in reflecting us, lets us reflect on who we are, offers epiphanies" (Mora, 1997, p. 272). In order to reveal the interconnectedness between Catholic spirituality and the unconscious, she explores the transmission of sensory memories. Frequently, she stimulates the auricular sense to encapsulate and transmit something essential yet elusive that occupies the family space. She condenses the history of generations to "slow conversations", and reduces them to "voices". The reader's attention is drawn to hear the voices that reverberate from the domestic space:

This is a "world that we can call our own", this family space through which generations move, each bringing its gifts, handing down languages and stories, recipes for living, gathering around the kitchen table to serve one another; in the walled garden, engaging in the slow conversation of families sitting to pass the time. Voices mingle with the voice of the fountain, parrot, broom, wind, voces del jardín. (Mora, 1997, p. 7)

Hearing the sounds of the rolling pin at the ranch, Aunt Elena says that "sounds seep into a body or a house. Be careful what you let within these walls. And where is the crucifix, I keep asking. Every good kitchen needs a small altar, candles we can light dedicating our work to the honor and glory of Our Lord” (Mora, 1997, p. 71). The Aunt Elena episode guides readers to follow her flow of thought from a rolling pin, food, and kitchen to an altar and finally “Our Lord”. The underlying association between sense perception and habitual religious behavior is so prevalent that readers can easily recognize similar episodes throughout the memoir.

I savor each simple gesture in this kitchen, filling the tea kettle, lighting the stove, click of the cup in the saucer. They've all been here, are here, the family of women, nursing one another with teas-de canela, hierba, gordolobo. Straight and erect in their good health or bent with age and arthritis, sacramental acts for another woman, or a husband, 
father, or child, steeping an old cure that began underground. "It is strange to be so many women" as Adrienne Rich says. (Mora, 1997, p. 11)

The process of awareness of female relatives' presence needs a more concrete and personal mode than mere cognitive remembrance, requiring a channel more deeply embedded in her own body. Mora highlights the act of savoring, which permits her to encounter them through smells. It is because the fragrance immediately enables her to remember what is engraved in her memories. Thus, the act of savoring becomes remembering and articulating the women's services in the kitchen and sacramental acts. In this episode, their intermingling with smells and savors is not only for philosophizing on the significance of food but also for fulfilling sacramental acts performed by themselves.

Mora points out that stopping the practice of religious formalities is easier than eradicating one's ingrained religious metaphors. Certainly, such metaphors associated with religious formalities often underlie structures and details of family life. To bring herself and her readers to a fuller appreciation of such insider material, she textures every page of her memoir with details of Catholic Chicano life (Christian, 2000, p. 121). The parallelism between smell, color, and religious figure illustrates that their Catholicism can be translated as the habits, symbols, and words embedded in the circular itinerary of family life: "The seasons should be respected and savored for what they bring, just as we savor the liturgical seasons, el año liturgico, like Advent, these four weeks of anticipation” (Mora, 1997, p. 276).

In the December chapter, Mamá Cleta reminds the family of the importance of religious rituals. Her "savoring" of Christmas is soon articulated by the scent of dry herbs and the color of flowers. She adds,

I’ve saved some dry herbs to scent the resting place para El Niño Dios. We'll send someone to buy flores de nochebuena that grow into bushes in México, the bracts turned into red by the tears of a devout boy with no gift for the Christ Child. (Mora, 1997, p. 276)

Mamá Cleta explicitly shows that their sensory experiences even in habitual behaviors are nearly systematically synchronized with the sensations which are evoked by religious stories and their implications. Mamá Cleta's account of religious rituals embedded in sense-perception evinces that there is no separation between the cognitive and perceptive dimension in their religious life. Perception, cognition, and reflection are so intermingled in experience as to become wholly integrated.

Merleau-Ponty's theory on phenomenological body offers useful groundwork to gain a basic understanding regarding the sense-perception mentioned above. In Phenomenology of Perception, Merleau-Ponty (2002) argues that "it is the body which speaks" (p. 197). This statement means that the body is an expressive and intentional body and, as such, a source of meaning. He suggests that the most primordial level of experience is embodied perception, not pure consciousness (p. 218). His analysis of embodied perception undermines the subject-object dichotomy of traditional epistemology; the percipient and the perceived are together in the same perceptual field. As he asserts that "my body is the fabric into which all objects are woven, and it is, at least in relation to the perceived world, the general instrument of my 'comprehension'” (Merleau-Ponty, 2002, p. 273); in this vein, it can be understood that Mora reassesses sense-perception as something vital-transcending the dualism of the mind and body, self and world.

One sense arouses another: they are so intrinsically interconnected that one easily becomes a stimulus of the other. Mora fills the space of pages with simultaneous invocation of sensory representations. She invites readers to experience the overlap of two different senses, that is, synesthesia: "prayers and faith weave through 
our relatives' words like floral scents weave through the garden” (Mora, 1997, p. 16). Rebolledo (1999) agrees that prayers are acknowledged both as words and voices, and naturally as scents.

Throughout the book, Mora especially portrays the women at work, talking, philosophizing, and remembering. They are intimately connected with senses and smells, with eating and spices, and with gardens. The descriptions of women and the work they do are so sensual as to create a virtual texture imbued with synesthesia: multiple sensory aspects of touch, smell, sight, taste, and sound. (p. 50)

Her analysis points to the prevalence of synesthesia in all the realms of female lives. According to Merleau-Ponty, synesthesia is said to occur because the unity and diversity of the senses can amount to a form of shared existence per se. He conveys how it technically works: "when I say that I see a sound, I mean that I echo the vibration of the sound with my whole sensory being, and particularly with that sector of myself which is susceptible to colors” (Merleau-Ponty, 2002, p. 272). His explanation illustrates how Mora appropriates the senses in such a way that they translate each other without any intrusion, in accord with their own transmissible structure (p. 273). Mora's description of synesthesia posits sense-perception as a creative receptivity that is inseparable from modalities of being itself. It particularly presents itself while translating religious experiences.

We read in a book on Persian gardens, about a hundred-petaled rose and the custom of sprinkling guests with rose water, of consuming the essence of the mesmerizing flower in rose preserves and sherbets. Mamá Cleta, never embarrassed by her synesthesia, sighs, “¿La oyes? Do you hear organ music when you look long the yellow rose?”. (Mora, 1997, p. 10)

Mamá Cleta's question reveals how deeply Catholic practices are involved in her perception of a subject. The question also shows the way in which religion exerts a determinative reference for daily life and a prevalent sensory modality. Just as the remembrance of sense is linked to the unconscious, liturgical performance subtly unfolds in unconscious sensory representation. This fact indicates that the meaning of the religious rituals, as opposed to what is learned by moral discipline, remains deep in their subliminal realm. By asking, "How much does our body know that we know not? Can it be cajoled to release it secrets?" (Mora, 1997, p. 2), she paradoxically emphasizes the density and firmness of what the senses know, given that what the body knows is stored in the unconscious. Consequently, searching for her memories in the unconscious is always linked to exploring her own senses and becoming in tune with them.

Mora reveals that the response of the senses is also needed to recall the souls of the dead since sense becomes a bodily agency that allows the living and dead to communicate with one another. In recalling the ancestor's spirits, Mora (1997) says that they "have no use for cemeteries, staying underground. They drift through the rooms like incense, like a prayer, a melody, a breath” (p. 268). Spiritual presences appear accompanied by the spirits' smell and sound. Their smell and sound saturate the space in such an organic way that the traces are not effaceable in the present.

In the November chapter, Aunt Chole covers an altar with a white tablecloth and adds "tiny coffins made of hard sugar-purple, blue, pink; sugar skulls staring at us with their foil eyes, miniature plates, breads, candy baskets, bananas, flowers, candles” (Mora, 1997, p. 253). She explains, "The dead are lured back by what they love, sweet temptations” (p. 157). In a similar vein, sensory communications between the living and the dead also offer the family a concealed way of incorporating communal experience into performing religious rituals. The spontaneous decoding of the spirits as sensory presences provides them with an unsanctioned religious path for expressing the sensuousness as well. Mora might say that it is an awareness resulting from 
verbalization of what she configures by exploring her dream house, that is, the unconscious. To her, writing certainly means free expression of sense-perception: embracing her sensuousness, communal conversation, and unconscious reflection, which have ultimately become the modalities of being in her family.

\section{The Corporeality and Re-envisioning of Popular Catholicism}

What Mora seeks to literalize in women's lives is interrelated with her spiritual reassessment of femaleness. There are several voices interweaving the stories, albeit all the voices are uttered through Mora's revision. Since most of the chapters are unveiled through women's stories, recipes, and activities, their presence is effectively transmitted through her visualization of their daily lives. Mora shows some significant episodes as performative religious representation to reveal how women in the family personify Catholicism. In these performative ways, they generate records and transmit knowledge in the form of memory.

Ygnacia Delgado, Mora's maternal aunt, who is better known by her nickname Lobo, becomes one of her main informants. Mora describes her as an "irrepressible storyteller" (p. 20). She provides central memories based on which Mora delineates the core story of the family's life. Lobo's narrated stories, devoid of her own private life, make Mora wonder how she selects and keeps them. By actualizing her story, she reveals how memory-images can be developed into narration.

Aunt Lobo who is portrayed at once as a domestic goddess and priestess offers eternally patient, giving, concerned love and devotion to her "children" even though they are not her own biological descendants. Thus motherhood is ascribed to her: "sensing, though unable to understand, the dark, pulsing depths of love, its wild abandon of the self, the pain she would inflict to protect us, we're both terrified and safe" (Mora, 1997, p. 40). Positioning Lobo in this manner, she validates the idea that real experience constitutes fertile ground for reconfiguring the meaning of motherhood. Mora's brother Roy notes: "She'd sail us to sleep, work her nightly magic, securing our night voyage. Prayers were her passion, her fragrance, her melody. With sweeps of her hand, she'd build crosses of air” (Mora, 1997, p. 40). Lobo evoked through sense-memory is commemorated with transcendental images: "Lobo, the frustrated, frenzied sweeper and cleaner, struggled to control the gritty desert and its wildness, but also to clear space for a more genteel life, a clean life, a pure life” (Mora, 1997, p. 41).

Unlike Chicana writer, Gloria Anzaldúa who strongly criticizes Catholicism and favors the Indian over the Spanish tradition, Mora rather focuses on positive values unraveled in her relatives' lives instead of utterly criticizing the negative aspects of Catholicism. Mora does not wholly rebuke the ritualized practices of Catholicism, nor does she rebel against the oppressive moral messages it has imposed on women. Instead, she attempts to recapture what really underlies formal religion, in order to reveal "culturally plural truths" remaining in the women's religiosity: motherhood, sacrifice, and self-discipline. One of Mora's remarks on femaleness provides an important insight: "Women see the psychological value of bringing their spirit and talents into the world for its betterment while developing the capacity for protecting and nurturing. Selfishness is no virtue" (interview with Oliver-Rotger). She connects femaleness to an unconditional love and unselfishness whose implications in her reality at times do not necessarily correspond with the sacred virtues that official Catholicism has inspired. She surmises that the concepts have never been totally encapsulated by the framework of traditional Catholicism, nor by any syncretic religion.

Aunt Chole, who is nearly blind and lives alone despite enduring several hardships, is depicted as a mystical nun. She is capable of noticing and sensing what normal people cannot see: "my aunt says she sees 
with her hands” (Mora, 1997, p. 136). Her confession can be understood in the same sense as in medieval mysticism where, in a certain devotional act, visual perception gives way to a more diffuse and bodily sense perception as the mystic finds herself "touched" by the image, as Mary Carruthers illustrates through the medieval spectator: "the early writers make no distinction between auditory, tactile or olfactory memory and visual memory on the basis that sensory impressions are received through the ranges of senses" (Carrthers, 1990, p. 17). Aunt Chole's faith stems from the loss of vision since the absence of sight ultimately enables her to surpass the suffering and to experience a mystical encounter with the "Sacred Heart". She recalls, "When I woke up this morning, I have my eyes closed, but I see. I see el Sagrado Corazón, there at the corner of my bed. He looks as if He is made of four pieces, of plaster, and I think, 'Just look. I can see His heart'” (Mora, 1997, p. 139). This confession reveals that mystical experience happens in an ordinary routine, not merely in times of devotion. In this scene, Mora, by taking a role of a female hagiographer, engages in addressing spiritual truths and divine experience that Aunt Chole articulates as a speaking subject. It can be said that Aunt Chole is portrayed as a female mystic. In Sensible Ecstacy, Hollywood (1999) argues that "feminist philosophy can learn from the doubleness of mystical discourse and practice, which reflects and speaks to the deep ambiguities within bodily existence” (p. 278). By reading female mystics who are poised between the desire to transcend the body's limitation and the recognition that transcendence occurs only through the body, Hollywood implies the possibility of devising new ways to think of desire in the juncture of the political, the religious, and the mystical. Drawing on this theory, Mora's description of mystical experience can be seen not only as a fictional representation, but also interpreted as her attempt to understand the spiritual meaning that underlies the "real" through sensory perception.

She asks herself "who is living, who is dead?" (Mora, 1997, p. 253). Since both presence and absence have an equal role in the composition of any discourse, what she wants to say through "the revelry of present absences?” (Torres, 1998, p. 236) is related to her perception of cyclical and heterogeneous time. Indeed, it implicitly reveals her philosophical/ontological worldview, suggesting that the heterogeneity of time could allow her another access to the "real", beyond the limits of historical time.

\section{“Lo cotidiano" and the Appropriation of Religiosity}

Even though the women in her memoir are, of course, not theologians, they share some core ideas with Hispanic/Latino theologians with regard to Christianity's essential and ultimate aims. One important example is that their understanding of "lo cotidiano" is a locus for inherited traditions as well as ongoing spirituality. In effect, their appreciation for lo cotidiano leads them to acknowledge that there is no disconnection between the secular and the sacred.

Isasi-Díaz (1996) explains the importance of lo cotidiano as a hermeneutical framework:

Lo cotidiano for us is also a way of understanding theology, our attempt to explain how we understand the divine, what we know about the divine. I contrast this to the academic and churchly attempts to see theology as being about God instead of about what we humans know about God. (p. 71)

In the same vein, Mora mostly illustrates an intimate encounter or real conversation with the divine, not mere repetition of conventional prayers. Aunt Chole answers Mora’s question, "Prayers you learned a long time ago?” with "No, no, I don’t like those novenas or prayers in books. I pray my way, and no one is going to change that, I say, 'Mi Diosito, help me to stay here in our home until the last days of my life.'... I just talk to 
Him like that. I just say what comes out of me, lo que me sale” (Mora, 1997, p. 279). Mora implicitly resists the formality of Catholicism in this portrayal of Aunt Chole, who speaks in her own ordinary language as she prays rather than in the official utterances that the Church prescribes.

Traditionally associated with the mind in the mind/body binary, official Catholicism removes sensuous joy from what their "cotidiano" spirituality offers them. Removing conscious conformity to religious formality, they simply express joy in performing religious actions, which emphasize immediacy and individuality. Along with narrative eloquence, visual imagining plays a central role in embodying personal relationships with religious figures. Remembering the figure of Jesus, Aunt Chole asserts, "He is dressed in a dry green, and I can see His pretty pink face and curly hair. I'm not sacred. I can't see, but I can see the pleats in His robe” (Mora, 1997, p. 279). Inner visual perception gives Aunt Chole power to attain religious faith based on her inspiration and psychology, rather than through a mediatory agency. Mora effectively demonstrates how wonderful it is to engage corporeality to formulate and perform their spirituality. In Our Cry for Life, liberation theologian Maria Pilar Aquino discusses the fact that liberation can only be accomplished through "the full restitution of human corporeality... because it is there in the body where the human person enacts the spiritual and material acts and no where else" (Aquino, 1993, p. 160).

Like Aunt Chole, in the September chapter, Mamá Cleta shows the family how to reappropriate the sacred symbols of the Virgin and Jesus. She invites Saint Rafael, Our Lady of Guadalupe, and all her favorite saints to the feast of San Rafael. Wistful Mamá Cleta deftly delineates the figure of Our Lady of Guadalupe, and the sensory contact with the religious figures in lo cotidiano allows her to represent their presences in a fictional and also a performative way:

Quickly, Nuestra Señora reaches for the pan dulce, sinks her teeth into the sweet bread, says as soon as she's swallowed, “Ay qué delicioso! Forgive me”, she laughs licking the last bits of topping from her firgertips, “I just couldn’t wait. Pan dulce is one of my weaknesses. Please, sit, sit. Doña Anacleta, how can I help? How kind of you to invite us into this wonderful garden on the feast of San Rafael”. (Mora, 1997, p. 231)

While highlighting that they generate records and transmit religious knowledge to next generations in these performative ways, Mora engages herself in delivering what are kept in the form of memory through rendering its dramatic version. This kind of memory can be understood as “archival memory” in Taylor's (2003) terms. In The Archive and the Repertoire, Taylor interprets embodied performance primarily as expressive transmission of knowledge based on epistemic and mnemonic systems. Since "the process of selection, memorization or internalization, and transmission takes place within specific systems of re-presentation" (Taylor, 2003, p. 21), "archival memory" retains the hermeneutical values of generational interaction and meditation, a constant state of presentness and againness. Similarly, women's performative appropriation of religious figures points to hermeneutical method transmitted by generational contact in appropriating official Catholicism and proposing alternative ways to it.

The "performative characteristics" in family ritual expresses what relates to their experience, precisely what resonates within their bodily senses. For example, Jesus is represented in response to their affective imagery. In The Future of Ritual, Schechner (1995) argues that "the future of ritual is the continued encounter between imagination and memory translated into doable acts of the body" (p. 263). His assertion is valid for the family ritual. The ritual in performative form and imagination has operated and certainly will remain in conjunction with the affective intensity of sense-memory and imaginative interpretation. 
Accordingly, Mora's representation of the Virgin rich with performative features helps readers to get a clear glimpse of her singular feminist perspective. It is not unusual for the articulation of the figure of the Virgin of Guadalupe to be an image of feminist strength. However, her account of the Virgin of Guadalupe as a wistful and friendly mother alludes to the fact that Mora does not exclusively depend on the presence of the Virgin of Guadalupe as a symbol of liberation and empowerment. In fact, she says, “I don't think that Our Lady of Guadalupe is so important for me that I would define her as a force in my life” (Mora, cited in Ikas, 2002, p. 141). Mora aims at broadening and deepening the femaleness which is hermeneutically monopolized by religious discourse in their community.

Defining her feminism, Mora says that her interest in issues of power leads her to write in order to resist internalized oppression. She thinks that some authors' versions of the Latino life are too "heavy-handed" or didactic, at least for her artistic taste (interview with Norma Alarcón, p. 125), and this view may be implicit evidence of her quiet resistance. Her path toward resistance is to highlight the performativity of the divine characters. Even though the memoir is not articulated in theological language, Mora shows that the women are obviously seeking for a meaning of the divine, not as a theological definition that has historically been imposed on the community, but as plural ways of experiencing the divine understood through performative representations embedded in lo cotidiano.

\section{Conclusion}

In opposition to official Catholicism whose transcendental orientation was apt to lead to an underestimation of the present, Mora endeavors to reinterpret the role and meaning of religion based on the present by engaging in sensory acquisition. Aligning with the sense of the "popular" of "popular religiosity", Mora aspires towards the transcendental, the existence of which she can intuit through the commonalities of community. Since an un-corresponding symmetry has existed between official Catholicism and what the community really considers as divine revelation, she alternatively portrays what can be termed as "the popular Catholicism" as a religiosity that should bridge the gap between the two; it is the communally shared experiences of the sacred.

Mora engages in rehabilitation of the sensible body in order to reassess communal spiritual values. Mora implies that religiosity, as one aspect of daily life, is perceived as what has been felt, through revealing the worldview formulated by sensory engagement. In effect, whole senses experienced in fullness are in tune with a spiritual sense. She presents family parties in which religious figures and the deceased gathered, with what García-Rivera (1999) calls "fullness of sensing" (p. 173) in Community of the Beautiful and "fullness of the cosmos" (p. 172). According to his ideas, the sensing of the world entails "sensing" both the material and spiritual dimensions of the world (p. 173); accordingly, Mora implicates the cosmos of the visible and the invisible by exploring the sensible body.

\section{References}

Alarcón, N. (1986). Interview with Pat Mora. Third Woman, 3(1-2), 121-126.

Aquino, M. P. (1993). Our cry for life: Feminist theology from Latin America. Maryknoll: Orbis Books.

Bachelard, G. (1994). Poetics of space. Boston: Beacon Press.

Carrthers, M. (1990). The book of memory: A study of memory in Medieval culture. Cambridge: Cambridge University Press Christian, B. M. (2000). Folk Catholicism in the works six U.S. Latina writers (Ph.D. diss., Indiana: Indiana U of Pennsylvania). García-Rivera, A. (1999). The community of the beautiful. Collegeville: The Liturgical Press. 
Hollywood, A. (1999). Sensible ecstasy: Mysticism, sexual difference, and the demands of history. Chicago: The University of Chicago Press.

Ikas, K. R. (2002). Chicana ways: Converstaions with ten Chicana writers. Reno: U of Nevada Press.

Isasi-Díaz, A. M. (1996). Mujerista theology. Maryknoll: Orbis Books.

Merleau-Ponty, M. (2002). Phenomenology of perception. New York: Routledge.

Mora, P. (1997). House of houses. Boston: Beacon Press.

Oliver-Rotger, M. A. (2003). Battlegrounds and croosroads: Social and imaginary space in writings by Chicanas. New York: Rodopi.

Rebolledo, T. D. (1999). The tools in the toolbox: Representing work in Chicana writing. Genre, 32, 41-52.

Schechner, R. (1995). The future of ritual: Writings on culture and performance. New York: Routledge.

Taylor, D. (2003). The archive and the repertoire: Performing cultural memory in the Americas. Durham: Duke University.

Torres, H. A. (1998). House of houses by Pat Mora. Aztlán, 23(2), 233-238. 